\title{
Upaya Meningkatkan Aktivitas Dan Hasil Belajar IPA Siswa kelas III Semester Satu Tahun Pelajaran 2018/2019 di SD Negeri 38 Ampenan Dengan Menerapkan Model Small Group Discussion (Diskusi Kelompok)
}

\author{
Mardiana \\ Guru Kelas III SD Negeri 38 Ampenan
}

\begin{abstract}
Abstrak. Penelitian ini bertujuan untuk mengetahui efektifitas penerapan model pembelajaran Small Group Discussion dalam upaya meningkatkan aktifitas dan hasil belajar IPA siswa kelas III SD Negeri 38 Ampenan. Manfaat penelitian ini adalah sebagai bahan kajian dan bahan temuan dalam pelaksanaan proses pembelajaran di kelas senyatanya. Bagi guru untuk meningkatkan kompetensi dalam proses pembelajaran dan bagi peserta didik untuk meningktakan aktifitas dan hasil belajar siswa. Penelitian ini dilaksanakan dua siklus, masing-masing siklus kegiatannya adalah; perencanaan, pelaksanaan, observasi dan refleksi. Hasil akhir tindakan pada siklus II pertemuan II menunjukkan bahwa hasil observasi guru memperoleh skor rata-rata $(4,57)$ dan hasil observasi peserta didik mencapai skor rata-rata $(4,65)$. Sedangkan hasil belajar peserta didik adalah mencapai nilai rata-rata $(81,68)$, artinya indikator keberhasilan $(\geq 75,00)$ telah terlampaui. Karena indikator keberhasilan telah terbukti penelitian dinyatakan berhasil dan dihentikan pada siklus II.
\end{abstract}

Kata Kunci : Aktifitas dan hasil Belajar-model Small Group Discussion

PENDAHULUAN

Latar Belakang

Dalam proses pembelajaran yang mendambakan siswa menjadi aktif, inovatif, kreatif, efektif, dan menyenangkan (PAIKEM) sangat dibutuhkan kondisi yang enjoy artinya biarkan siswa rebut di kelass tetapi ributnya itu dalam rangka mendiskusikan tugas yang diberikan oleh guru. Biarkan siswa bebas bergerak selama ada hubungannya dengan proses pembelajaran. Kalau suasana itu dapat berjalan sesuai dengan yang diharapkan maka aktivitas dan hasil siswa dapat ditingkatkan. Aktivitas siswa dalam proses pembelajaran dapat dilihat/diamati ketika sedang proses diskusi kelompok kecil dalam menyelesaikan masalah yang diberikan oleh guru. Hasil belajar yang dimakssudkan dalam tulisan ini adalah hasil kerja kelompok yang dibuat oleh masingmasing anggota kelompok dan tes tertulis yang dilaksanakan pada akhir pembelajaran. Sejatinya aktivitass dan hassil belajar siswa itu adalah merupakan penentu berhasil tidaknya siswa selama mengikuti proses pembelajaran yang berlangsung, dan dijadikan sebagai penentu bagi guru dalam merencanakan program tindak lanjut.

Proses pemelajaran di kelas III SD Negeri 38 Ampenan khususnya pada mata pelajaran IPA kesehariannya dapat dijelaskan sebagai berikut: 1) kondisi siswa ketika guru sedang menyampaikan materi pelajaran masih banyak dijumpai yang rebut, bermain-main sendiri/bersama teman sekelasnya, 2) ketika diberikan tugas secara berkelompok (diskusi kelompok) terkesan hanya cuek saja, yang bekerja paling hanya satu atau dua orang, sementara yang lain sibuk dengan bermainmain dan berperilaku aneh-aneh, 3) ketika diberikan tugass mandiri, banyak siswa yang kebingungan, hal ini terjadi karena siswa tidak pernah mendengarkan penjeasan guru, 4) ketika diadakan tes tertulis pada akhir pelajaran banyak yang tidak bisa mengerjakan dengan baik dan benar. Memperhatikan kondisi yang demikian, guru selaku peneliti menyimpulkan untuk sementara bahwa aktivitas dan hassil belajar siswa kelas III pada mata pelajaran/bidang studi IPA massih rendah. Rendahnya aktivitas dan hasil belajar siswa 
disebabkan karena proses pembelajaran tidak berjalan sebagaimana mestinya (kurang kondusif).

Rendahnya aktivitas dan haasil belajar IPA siswa kelas III semester satu tahun pelajaran 2018/2019 di SD Negeri 38 Ampenan disebabkan Karena; 1) tingkat usia kelas II adalah dunia bermain, sehingga walaupun dengan metode apa saja siswa tetap senang bermain sambil mendengarkan dan mengerjakan tugas dari guru, 2) waktu efektif belajar dan bermain masih cenderung banyak mainnya daripada seriusnya, dan 3) lebih banyak bermain daripada mengerjakan tugas mandiri yang diberikan oleh guru kelas. Disamping ketiga factor penyebab ada juga yang berasal dari guru, metode pembelajaran yang dipakai oleh guru masih cenderung mengarah ke guru sentris, sehingga dalam proses pembelajaran siswa terkesan dicekoki dengan materi-materi yang sebenarnya siswa belum mampu memahaminya.

Banyak solusi yang dapat dilakukan oleh peneliti dalam upaya meningkatkan aktivitass dan hassil belajar IPA siswa kelas III semester satu tahun pelajaran 2018/2019 di SD Negeri 38 Ampenan, yaitu dengan menerapkan model pembelajaran "Small Group Discussion (Diskusi kelompok kecil". Adapun alas an mengambil model small group Discussion ini adadlah karena model pembelajaran ini memiliki keunggulan bila dibandingkan dengan dengan model pembelajaran yang lain. Keunggulan model small group Discussion ini adalah; 1) mampu menggerakkan motivasi dan aktivitas belajar siswa, 2) menumbuhkan nilai demokratis, percaya diri, dan rasa ingin tahu bagi siswa, 3) menumbuhkan rasa kesetiaaan social terhadap sesame siswa begitu juga dengan guru, orang tua, masyarakat, bangsa dan Negara yang pada gilirannya bisa menjadi manusia pancasilais yang sejati.

Mengingat model "Small Group Discussion" memiliki beberapa keunggulan bila dibandingkan dengan model pembelajaran yang lain, maka untuk membuktikan dugaan itu perlu diadakan Penelitian Tindakan Kelass (PTK) dengan judul "Upaya Meningkatkan Aktivitas Dan Hasil Belajar IPA Siswa kelas III Semester Satu Tahun Pelajaran 2018/2019 di SD Negeri 38 Ampenan Dengan Menerapkan Model Small Group Discussion (Diskusi Kelompok)".

\section{Rumusan Masalah}

"bagaimana menerapkan model Small Group Discussion (diskusi kelompok) pada pembelajaran IPA siswa kelas III semester satu Tahun Pelajaran 2018/2019 di SD Negeri 38 Ampenan upaya meningkatkan aktivitas dan hasil belajar siswa?"

\section{Tujuan Penelitian}

"Untuk mengetahui efektifitas penerapan Small Group Discussion dalam upaya meningkatkan aktivitas dan hasil belajar IPA siswa kelas III SD Negeri 38 Ampenan Semester satu tahun pelajaran 2018/2019”.

\section{Manfaat Penelitian}

a. Bermanfaat bagi guru selaku peneliti dalam rangka melaksanakan proses pembelajaran yang kontekstual melalui penerapan Small Group Discussion di kelas senyatanya serta dalam upaya perwujudan pembelajaran yang aktif, inovatif, kreatif, efektif, dan menyenangkan (PAIKEM) sehingga aktivitas dan hasil belajar siswa dapat ditingkatkan.

b. Bermanfaat bagi siswa dalam upaya meningkatkan prestasi belajar siswa.

\section{KAJIAN PUSTAKA \\ Kerangka Teoritis \\ Aktivitas Belajar}

Belajar sangat dibutuhkan adanya aktivitas, dikarenakan tanpa adanya aktivitas proses belajar tidak mungkin berlangsung dengan baik. Pada proses aktivitas pembelajaran harus melibatkan seluruh aspek siswa, baik jasmani maupun rohani sehingga perubahan perilakunya dapat berubah dengan cepat, tepat, mudah dan benar, baik berkaitan dengan aspek kognitif afektif maupun psikomotor (Nanang Hanafiah, 2010:23).

Aktivitas belajar adalah aktivitas yang bersifat fisik maupun mental. Dalam proses belajar kedua aktivitas itu harus saling 
berkaitan. Lebih lanjut lagi piaget menerangkan dalam buku Sardiman bahwa jika seorang anak berfikir tanpa berbuat sesuatu, berarti anak itu tidak berfikir (Sardiman, 2011:100).

Nanang Hanafiah dan Cucu Suhana (2010:24) menjelaskan bahwa aktivitas belajar dapat memberikan nilai tambah (added value) bagi siswa, berupa hal-hal berikut ini:

1. Siswa memiliki kesadaran (awareness) untuk belajar sebagai wujud adanya aktivitas internal untuk belajar sejati.

2. Siswa mencari pengalaman dan langsung mengalami sendiri, yang dapat memberikan dampak terhadap pembentukan pribadi yang integral.

3. Siswa belajar dengan menurut minat dan kemampuannya.

4. Menumbuh kembangkan sikap disiplin dan suasana belajar yang demokratis di kalangan siswa.

5. Pembelajaran dilaksanakan secara konkret sehingga dapat menumbuh kembangkan pemahaman dan berfikir kritis serta menghindarkan terjadinya verbalisme.

6. Menumbuh kembangkan sikap kooperatif dikalangan siswa sehingga sekolah menjadi hidup, sejalan dan serasi dengan kehidupan di masyarakat di sekitarnya.

Dalam penelitian ini yang dimaksud dengan aktivitas belajar adalah kegiatan siswa mengingat, memecahkan masalah, menganalisis faktor-faktor, melihat hubungan-hubungan, dan membuat keputusan terhadap masalah yang diberikan oleh guru kelas III di SD Negeri 38 Ampenan.

\section{Hasil Belajar}

Masalah belajar adalah masalah bagi setiap manusia, dengan belajar manusia memperoleh keterampilan, kemampuan sehingga terbentuklah sikap dan bertambahlah ilmu pengetahuan. Jadi hasil belajar itu adalah suatu hasil nyata yang dicapai oleh siswa dalam usaha menguasai kecakapan jasmani dan rohani di sekolah yang diwujudkan dalam bentuk raport pada setiap semester.

Jurnal Ilmu Sosial dan Pendidikan
Untuk mengetahui perkembangan sampai di mana hasil yang telah dicapai oleh seseorang dalam belajar, maka harus dilakukan evaluasi. Untuk menentukan kemajuan yang dicapai maka harus ada kriteria (patokan) yang mengacu pada tujuan yang telah ditentukan sehingga dapat diketahui seberapa besar pengaruh strategi belajar mengajar terhadap keberhasilan belajar siswa. Hasil belajar siswa menurut W. Winkel (dalam buku Psikologi Pengajaran 1989:82) adalah keberhasilan yang dicapai oleh siswa, yakni prestasi belajar siswa di sekolah yang mewujudkan dalam bentuk angka.

Dari definisi di atas, maka dapat diambil kesimpulan bahwa hasil belajar adalah prestasi belajar yang dicapai siswa dalam proses kegiatan belajar mengajar dengan membawa suatu perubahan dan pembentukan tingkah laku seseorang. Untuk menyatakan bahwa suatu proses belajar dapat dikatakan berhasil, setiap guru memiliki pandangan masing-masing sejalan dengan filsafatnya. Namun untuk menyamakan persepsi sebaiknya kita berpedoman pada kurikulum yang berlaku saat ini yang telah disempurnakan, antara lain bahwa suatu proses belajar mengajar tentang suatu bahan pembelajaran dinyatakan berhasil apabila tujuan pembelajaran khususnya dapat dicapai.

Untuk mengetahui tercapai tidaknya tujuan pembelajaran khusus, guru perlu mengadakan tes formatif pada setiap menyajikan suatu bahasan kepada siswa. Penilaian formatif ini untuk mengetahui sejauh mana siswa telah menguasai tujuan pembelajaran khusus yang ingin dicapai. Fungsi penelitian ini adalah untuk memberikan umpan balik pada guru dalam rangka memperbaiki proses belajar mengajar dan melaksanakan program remedial bagi siswa yang belum berhasil. Karena itulah, suatu proses belajar mengajar dinyatakan berhasil apabila hasilnya memenuhi tujuan pembelajaran khusus dari bahan tersebut.

Dalam penelitian ini yang dimaksud dengan hasil belajar adalah laporan individu 
dan tes dalam bentuk tertulis yang materi soalnya hanya selintas apa yang disajikan oleh guru selama prose pembelajaran di kelas. Dalam hal ini adalah materi pembelajaran IPA kelas III.

\section{Model Pembelajaran Small group discussion}

Small group discussion adalah proses pembelajaran dengan melakukan diskusi kelompok kecil tujuannya agar peserta didik memiliki ketrampilan memecahkan masalah terkait materi pokok dan persoalan yang dihadapi dalam kehidupan sehari-hari. Small group discussion juga berarti proses penglihatan dua atau lebih individu yang berinteraksi secara global dan saling berhadapan muka mengenai tujuan atau sasaran yang sudah tertentu melalui tukar menukar informasi, mempertahankan pendapat atau pemecahan masalah.

Small group discussion sebagaimana pembelajaran kelompok lainnya memiliki unsur-unsur yang saling terkait, yakni:

1. Saling ketergantungan positif (positive interdependence).

Cooperative learning menghendaki adanya ketergantungan positif saling membantu dan saling memberikan motivasi sehingga ada interaksi diantara siswa.

\section{Akuntabilitas individual (individual accountability)}

Small group discussion menuntut adanya akuntabilitas individual yang mengukur penguasaan bahan belajar tiap anggota kelompok, dan diberi balikan tentang prestasi belajar anggotaanggotanya sehingga mereka saling mengetahui rekan yang memerlukan bantuan. Berbeda dengan kelompok tradisional, akuntabilitas individual sering diabaikan sehingga tugas-tugas sering dikerjakan oleh sebagian anggota. Dalam small group discussion, siswa harus bertanggungjawab terhadap tugas yang diemban masing-masing anggota.

3. Tatap muka (face to face interaction)

Small group discussion menuntut semua anggota dalam kelompok belajar dapat saling tatap muka sehingga mereka dapat berdialog tidak hanya dengan guru tapi juga bersama dengan teman. Interaksi semacam itu memungkinkan anak-anak menjadi sumber belajar bagi sesamanya. Hal ini diperlukan karena siswa sering merasa lebih mudah belajar dari sesamanya dari pada dari guru.

4. Ketrampilan Sosial (Social Skill)

Unsur ini menghendaki siswa untuk dibekali berbagai ketrampilan sosial seperti tenggang rasa, sikap sopan kepada teman, mengkritik ide, berani mempertahankan pikiran logis, tidak mendominasi yang lain, mandiri, dan berbagai sifat lain yang bermanfaat dalam menjalin hubungan antar pribadi tidak hanya diasumsikan tetapi secara sengaja diajarkan.

5. Proses Kelompok (Group Processing)

Proses ini terjadi ketika tiap anggota kelompok mengevaluasi sejauh mana mereka berinteraksi secara efektif untuk mencapai tujuan bersama. Kelompok perlu membahas perilaku anggota yang kooperatif dan tidak kooperatif serta membuat keputusan perilaku mana yang harus diubah atau dipertahankan.

\section{Tujuan Metode Small Group}

Sebagai metode belajar, belajar kelompok diskusi atau small group discussion mengandung tujuan yang ingin dikembangkan. Tujuan diskusi atau small group discussion antara lain :

1. Agar siswa berbincang-bincang untuk memecahkan masalahmasalah sendiri.

2. Agar siswa berbincang-bincang mengenai masalah-masalah apa saja yang berhubungan dengan kehidupan mereka sehari-hari, dengan kehidupan mereka di sekolah, dengan sesuatu yang terjadi di lingkungan sekitar mereka dan sebagainya.

3. Agar siswa berbincang-bincang mengenai pelajaran di kelas dengan maksud saling mengoreksi pemahaman yang mereka atas pelajaran yang diterimanya, agar masingmasing anggota memperoleh pemahaman yang lebih baik.

Dengan demikian, proses belajar mengajar perlu berorientasi pada kebutuhan dan 
kemampuan siswa, misalnya dengan pendekatan "inquiry-discovery learning". Kegiatan-kegiatan yang dilaksanakan di sini harus dapat memberikan pengalaman belajar yang menyenangkan dan berguna baginya. Guru perlu memberikan bermacam-macam situasi belajar yang memadai untuk materi yang disajikan, dan menyesuaikannya dengan kemampuan dan karakteristik serta gaya belajar siswa. Sebagai konsekuensi logisnya, guru dituntut harus kaya metodologi mengajar sekaligus terampil menerapkannya, tidak monoton dan variatif dalam melaksanakan pembelajaran.

\section{Langkah-Langkah dalam Metode Small Group}

Langkah-langkah penerapan metode small group discussion diantaranya :

a. Bagi kelas menjadi beberapa kelompok kecil (maksimal 5 murid) dengan menunjuk ketua dan sekretaris

b. Berikan soal studi kasus (yang dipersiapkan oleh guru) sesuai dengan Standar Kompetensi (SK) \& Kompetensi dasar (KD).

c. Instruksikan setiap kelompok untuk mendiskusikan jawaban soal tersebut

d. Pastikan setiap anggota berpartisipasi aktif dalam diskusi

e. Instruksikan setiap kelompok melalui juru bicara yang ditunjuk menyajikan hasil diskusinya dalam forum kelas

f. Klarifikasi, penyimpulan dan tindak lanjut (Guru)

\section{Kerangka Konseptual}

Hubungan antara variabel harapan (meningkatnya aktivitas dan hasil belajar siswa) dengan variabel tindakan (penerapan Small Group Discussion).

\section{Hipotesis Tindakan}

Penerapan Small Group Discussion dapat meningkatkan aktivitas dan hasil belajar siswa kelas III SD Negeri 38 Ampenan semester satu Tahun pelajaran 2018/2019”.

\section{METODE PENELITIAN \\ Setting Penelitian}

Penelitian tindakan kelas (PTK) ini akan dilaksanakan di kelas III SD Negeri 38 Ampenan semester satu tahun pelajaran 2018/2019, dengan jumlah siswa sebanyak 20 orang.

\section{Faktor yang Diteliti}

1. Faktor Guru: yaitu dengan mengamati cara guru membuat Rencana Pelaksanaan Pembelajaran (RPP) dan pelaksanaannya dalam pembelajaran di kelas senyatanya dengan menerapkan model Small Group Discussion dalam upaya meningkatkan aktivitas dan hasil belajar IPA siswa Kelas III SD Negeri 38 Ampenan.

2. Faktor Siswa: yaitu peningkatan aktivitas belajar siswa yang terlihat pada saat melaksanakan diskusi kelompok, dan pada saat tes tertulis di akhir pembelajaran bagi siswa kelas III Semester satu Tahun pelajaran 2018/2019 di SD Negeri 38 Ampenan.

\section{Rencana Tindakan}

kegiatan nyata di kelas III yaitu melaksanakan proses pembelajaran dengan menerapkan model Small Group Discussion dalam upaya meningkatan aktivitas dan hasil belajar IPA siswa kelas III SD Negeri 38 Ampenan semester satu tahun pelajaran 2018/2019. Tindakan nyata yang dilakukan oleh guru selaku peneliti adalah dengan menggunakan siklus. Gambaran siklus dalam penelitian ini adalah sebagai berikut:

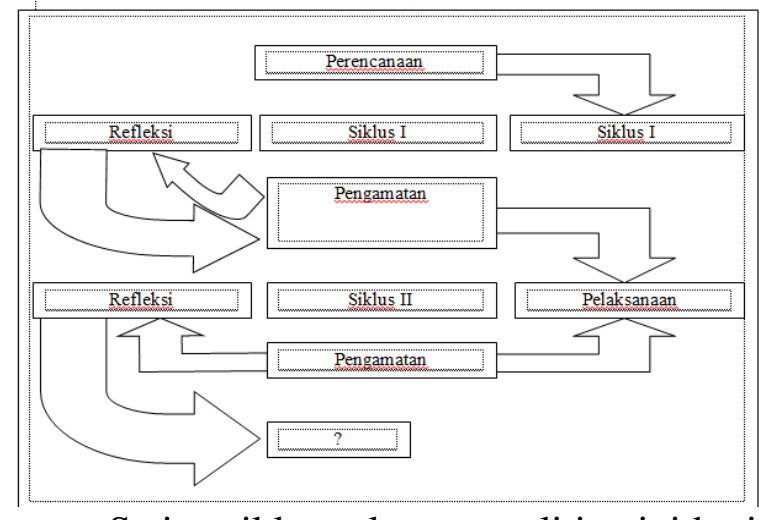

Setiap siklus selama penelitian ini berisi

4 (empat) tahapan yaitu: 1) Perencanaan 
(Planning), 2) Pelaksanaan (Action), 3) Observasi (Observation), dan 4) Refleksi (Reflection).

\subsection{Siklus Tindakan}

Masing-masing tahapan dalam setiap siklus berisikan kegiatan-kegiatan nyata yang akan dilaksanakan. Untuk mendapatkan tentang rincian kegiatan pada setiap tahap dapat dijelaskan sebagai berikut:

\section{SIKLUS I}

\section{Tahap Perencanaan (Planning)}

1. Menyusun Rencana Pelaksanaan Pembelajaran (RPP) dengan skenario sesuai dengan aturan main model pembelajaran Cooperatif learning (CL) tipe Jigsaw.

2. Menyiapkan sumber, bahan, dan semua alat yang digunakan dalam penelitian.

3. Menyusun/membuat lembar observasi guru dan lembar observasi siswa.

4. Menyusun alat evaluasi.

\section{Tahap Pelaksanaan (Action)}

\section{Pertemuan I}

1. Guru membagi siswa menjadi 5 (lima) kelompok kecil, masing-masing kelompok beranggotakan 4 orang siswa.

2. Guru memberikan soal/kasus yang sesuai dengan materi yang diajarkan pada hari itu

3. Masing-massing kelompok diinstruksikan untuk mendiskusikan soal/kasus yang diperoleh bersama anggota kelompok masing-masing

\section{Pertemuan II}

4. Setelah selesai berdiskusi, guru memberi instruksi kepada masing-masing kelompok untuk mempresentasikan hasil diskusi kelompok di depan kelas.

5. Guru memberikan klarifikasi, penyimpulan dan tindak lanjut dari hasil diskusi kelompok yang telah dilakukan

6. Tes tertulis

\section{Tahap Observasi (Observation)}

1. Observasi guru : Dilakukan oleh pengawas pembimbing dalam melaksanakan Penelitian Tindakan Kelas (PTK).
2. Observasi Siswa : Dilakukan oleh guru kelas sebagai peneliti dalam Penelitian Tindakan Kelas (PTK) pada kegiatan diskusi kelompok dan presentasi kelompok.

4). Tahap Refleksi (Reflection)

1. Renungan hasil perolehan data

2. Pengolahan dan analisa data hasil penelitian

3. Mencocokkan hasil analisa data dengan indikator keberhasilan

4. Rencana perbaikan dan tindak lanjut

\section{SIKLUS II}

Pada siklus ini semua kegiatan dan tahapan selama penelitian adalah sama, sifatnya mengulang dan memperbaiki terhadap tindakan yang masih memerlukan penyempurnaan dan pembenaran sebagaimana mestinya.

\section{Data dan Cara Pengambilannya.}

\section{Sumber Data}

Yang menjadi sumber data dalam penelitian tindakan kelas (PTK) ini adalah semua siswa kelas III SD Negeri 38 Ampenan semester satu tahun pelajaran 2018/2019 dan guru kelas/mata pelajaran IPA.

\section{Jenis Data}

- Jenis data yang berasal dari guru selaku peneliti

1). Data tentang Rencana Pelaksanaan Pembelajaran (RPP)

2). Data Pelaksanaan Pembelajaran

- Jenis data yang berasal dari siswa :

1). Data kemajuan aktivitas belajar

2). Data hasil laporan individu hasil diskusi kelompok

3). Data hasil belajar siswa/tes tertulis

\section{Cara Pengambilan data}

- Data kegiatan pembelajaran diambil dari RPP yang dibuat oleh guru dan lembar observasi pelaksanaan model pembelajaran Small Group Discussion

- Data kemajuan aktivitas belajar; diambil dari lembar observasi selama kerja kelompok dan presentasi kelompok.

- Data kemajuan hasil belajar; diambil dari laporan hasil kerja kelompok secara individual dan nilai hasil tes 
tertulis yang dilaksanakan pada akhir proses pembelajaran

\section{Indikator Keberhasilan dan Teknik analisa data \\ Teknik analisa data}

Untuk menganalisis data akan dilakukan melalui analisis deskriptif kuantitatif melalui pendataan, analisis dan pembahasan terhadap data yang diperoleh dengan mencocokkan tingkat keoptimalan terhadap capaian indikator keberhasilan yang ada.

\section{Indikator Keberhasilan}

- guru telah dinyatakan berhasil melaksanakan proses pembelajaran dengan pendekatan Small Group Discussion, bila telah mencapai skor rata-rata $\geq 4,00$

- aktivitas belajar IPA siswa kelas III dinyatakan telah meningkat jika $\geq 85 \%$ dari jumlah siswa telah memperoleh skor ratarata $\geq 4,0$ (kategori baik) dan hasil belajar dinyatakan telah meningkat jika $\geq 85 \%$ dari jumlah siswa memperoleh nilai rata-rata $\geq$ 75,00 (KKM Siswa).

\section{HASIL DAN PEMBAHASAN}

\section{Laporan Hasil}

\section{DESKRIPSI SIKLUS I}

\section{Tahap Perencanaan}

Pada tahapan ini yang telah dilakukan oleh guru selaku peneliti adalah; 1) menyusun RPP dengan skenario pembelajaran Small Group Discussion, 2) telah berhasil menyiapkan alat, sumber, bahan yang diperlukan dalam penelitian, 3) berhasil menyusun instrument observasi guru dan instrument observasi siswa, dan 4) menyusun alat evaluasi.

\section{Tahap Pelaaksanaan \\ Pertemuan I}

1. Guru membagi siswa menjadi 5 (lima) kelompok kecil, masing-masing kelompok beranggotakan 4 orang siswa.

2. Guru memberikan soal/kasus yang sesuai dengan materi yang diajarkan pada hari itu

3. Masing-massing kelompok diinstruksikan untuk mendiskusikan soal/kasus yang diperoleh bersama anggota kelompok masing-masing

\section{Pertemuan II}

4. Setelah selesai berdiskusi, guru memberi instruksi kepada masing-masing kelompok untuk mempresentasikan hasil diskusi kelompok di depan kelas.

5. Guru memberikan klarifikasi, penyimpulan dan tindak lanjut dari hasil diskusi kelompok yang telah dilakukan

6. Tes tertulis

\section{Tahap Observasi}

Observasi guru memperoleh skor rataarata pertemuan I $(3,21)$ dan pertemuan II $(3,43)$, observasi siswa memperoleh skor rata-rata pertemuan I $(3,35)$ dan pertemuan II $(3,70)$. Hasil belajar diperoleh dari tugas individual dan tes tertulis yang nilai rata-ratanya masingmasing sebesar $(70,80)$ dan $(68,15)$.

\section{Tahap Refleksi}

1. Renungan data hasil perolehan data pada siklus I

2. Pengolahan data hasil observasi guru, siswa dan tes tertulis.

3. Mencocokkan hasil yang ada dengan Indikator keberhasilan.

4. Merencanakan perbaikan terhadap jenis tindakan yang menyebabkan belum tuntas Indikator keberhasilan. Oleh karena Indikator keberhasilan belum terbukti maka penelitian dilanjutkan ke siklus II.

\section{DESKRIPSI SIKLUS II}

\section{Tahap Perencanaan}

Pada tahapan ini jenis kegiatan yang dilakukan masih mengacu pada kegiatan siklus I, bedanya hanya terjadi perbaikan seperlunya yaitu: 1) penyusunan RPP dengan mengacu pada pendekatan Small Group Discussion dan penyempurnaan pada bagian skenario pembelajaran, 2) menyiapkan alat, sumber, bahan yang diperlukan dalam proses tindakan dikelas senyatanyan, 3) menyiapkan lembar observasi guru dan lembar observasi siswa sebagaimana pada siklus I, 4) menyiapkan alat evaluasi sebagaimana yang telah dibuat pada siklus I.

\section{Tahap Pelaksanaan}


Secara umum tahapan pelaksanaan proses pembelajaran pada siklus II ini masih mengacu pada pelaksanaan proses pembelajaran sebelumnya. Yang dilakukan pada proses pembelajaran ini adalah: 1) pelaksanaan proses diskusi kelompok kecil lebih dioptimalkan, 2) pelaksanaan pembimbingan kelompok sekaligus observasi siswa lebih di efektifkan. Utamanya pengamatan siswa yang aktif, yang kurang aktif, siswa yang tidak aktif, dengan harapan proses analisa data lebih signifikan, 3)laporan hasil kerja kelompok yang dibuat secara individu lebih difokuskan, dan 4) pelaksanaan tes tertulis sebagai tolak ukur keberhasilan siswa lebih dioptimalkan.

\section{Tahap Observasi}

Observasi guru memperoleh skor rataarata pertemuan I $(4,21)$ dan pertemuan II $(4,57)$, observasi siswa memperoleh skor rata-rata pertemuan I $(4,20)$ dan pertemuan II $(4,65)$. Hasil belajar diperoleh dari tugas individual dan tes tertulis yang nilai rata-ratanya masingmasing sebesar $(80,95)$ dan $(82,40)$.

\section{Tahap Refleksi}

1. Renungan atas perolehan data hasil observasi guru, observasi siswa, dan hasil tes tertulis sebagai hasil dari peningkatan aktivitas dan hasil belajar siswa di kelas senyatanya.

2. Pengolahan data hasil observasi guru, observasi siswa dan tes tertulis

3. Mencocokkan perolehan data hasil tindakan dengan Indikator keberhasilan yang telah ditetapkan.

4. Guru memberikan hadiah/reward kepada semua siswa kelas III atas keberhasilannya dalam upaya meningkatkan aktivitas dan hasil belajar dan perolehan hasil belajar sesuai dengan KKM yang telah ditetapkan.

\section{Pembahasan}

SIKLUS I

\section{Tahap Perencanaan}

Peneliti telah menyusun RPP dengan skenario penerapan Small Group Discussion., menyiapkan alat, sumber, bahan yang diperlukan dalam proses pembelajaran, menyusun instrument observasi guru maupun instrument observasi siswa, mengalami beberapa kendala. Tetapi setelah berkonsultasi dan meminta petunjuk kepada pembimbing, akhirnya kendala pundapat diatasi dengan baik.

\section{Tahap Pelaksanaan \\ Pertemuan I}

1. Guru membagi siswa menjadi 5 (lima) kelompok kecil, masing-masing kelompok beranggotakan 4 orang siswa.

2. Guru memberikan soal/kasus yang sesuai dengan materi yang diajarkan pada hari itu

3. Masing-massing kelompok diinstruksikan untuk mendiskusikan soal/kasus yang diperoleh bersama anggota kelompok masing-masing

\section{Pertemuan II}

4. Setelah selesai berdiskusi, guru memberi instruksi kepada masing-masing kelompok untuk mempresentasikan hasil diskusi kelompok di depan kelas.

5. Guru memberikan klarifikasi, penyimpulan dan tindak lanjut dari hasil diskusi kelompok yang telah dilakukan

Kegiatan pembelajaran diakhiri dengan tes tertulis, hal ini dimaksudkan untuk mengetahui peningkatan hasil belajar siswa kelas III SD Negeri 38 Ampenan semester satu tahun pelajaran 2018/2019 dengan penerapan Small Group Discussion. Asumsi bila aktivitas dan hasil belajar meningkat maka akan terjadi peningkatan hasil belajar pula.

\section{Tahap Observasi}

Observasi guru memperoleh skor ratarata pertemuan I $(3,21)$, pertemuan II $(3,43)$. Hasil observasi siswa dalam upaya peningkatan aktivitas dan hasil belajar IPA siswa kelas III semester satu tahun pelajaran 2018/2019 di SD Negeri 38 Ampenan diperoleh skor rata-rata pertemuan I $(3,35)$ pertemuan II $(3,70)$. Perolehan nilai rata-rata tugas individual dan tes tertulis yang dilakukan pada akhir pelajaran adalah $(70,80)$ dan $(68,15)$ kategori cukup.

\section{Tahap Refleksi}

Hasil analisa data perolehan aktivitas dan hasil belajar pada siklus I pertemuan II ini 
$(3,70)$ sedangkan yang diminta dalam Indikator keberhasilan $(\geq 4,0)$, ini artinya belum berhasil.

Karena Indikator keberhasilan belum tercapai, penelitian tindakan kelas (PTK) dilanjutkan ke siklus II dengan harapan optimalisasi penerapan strategi pembelajaran dengan pendekatan Small Group Discussion dapat meningkatkan aktivitas dan hasil belajar IPA siswa kelas III semester satu tahun pelajaran 2018/2019 di SD Negeri 38 Ampenan.

\section{SIKLUS II}

\section{Tahap Perencanaan}

Peneliti menyusun Rencana

Pelaksanaan Pembelajaran (RPP) dengan memperhatikan kesalahan-kesalahan pada siklus I. peneliti lebih memfokuskan tentang Rencana strategi jitu sehingga proses pembelajaran dengan Small Group Discussion dapat terelaisasi dengan baik, karenanya dalam penyusunan skenario benar-benar dirinci dari tiap aspek pada proses pembelajaran dengan JIGSAW.

Sebelum proses pembelajaran dilaksanakan, peneliti menyiapkan semua alat, bahan, dan segala sesuatunya sehingga dalam pelaksanaan proses pembelajaran berjalan sesuai dengan skenario yang telah direncanakan. Agar proses pembelajaran dapat teratasi maka peneliti juga menyiapkan lembar observasi guru dan lembar observasi siswa sebagai tolak ukur ketercapaian peningkatan aktivitas dan hasil belajar IPA siswa kelas III SD Negeri 38 Ampenan.

\section{Tahap Pelaksanaan}

Pada tahap pelaksanaan di siklus II ini pada dasarnya masih mengacu pada pelaksanaan siklus I, yaitu penerapan Small Group Discussion. Bedanya pada siklus ini lebih dioptimalkan.

\section{Tahap Observasi}

Pada siklus II ini hasil observasi memperoleh skor rata-rata pertemuan I $(4,21)$ dan pertemuan II $(4,57)$. Upaya meningkatkan aktivitas dan hasil belajar IPA siswa kelas III semester satu tahun pelajaran 2018/2019 di SD
Negeri 38 Ampenan diperoleh skor rata-rata pertemuan I $(4,20)$, pertemuan II $(4,65)$. Dampak nyata dari meningkatnya aktivitas dan hasil belajar adalah prestasi belajar juga meningkat, dari data hasil perolehan nilai ratarata tugas dan tes tertulis adalah $(80,95)$ dan $(82,40)$ sementara pada siklus sebelumnya hanya $(70,80)$ dan $(68,15)$ berarti mengalami peningkatan yang signifikan.

\section{Tahap Refleksi}

Hasil analisa data peningkatan aktivitas dan hasil belajar siswa pada siklus II pertemuan II adalah $(4,65)$ sedangkan Indikator keberhasilan $(\geq 4,0)$. Ini artinya pada siklus II hasilnya telah melampaui Indikator keberhasilan. Hasil belajar pada siklus I $(69,48)$ sedangkan pada siklus II $(81,68)$, ini artinya indikator keberhasilan telah dilampaui.

Karena Indikator keberhasilan telah terbukti, maka tidak perlu ada upaya perbaikan dan penyempurnaan. Small Group Discussion telah mampu meningkatkan aktivitas dan hasil belajar siswa yang ditandai dengan tercapainya Indikator keberhasilan dan terjadinya peningkatan hasil belajar siswa. "Penelitian Tindakan Kelas (PTK) dihentikan pada siklus II dengan hasil memuaskan."

\section{Simpulan}

Penerapan model pembelajaran Small Group Discussion sangat efektif dalam upaya untuk meningkatkan aktivitas dan hasil dan hasil belajar IPA siswa kelas III semester satu tahun pelajaran 2018/2019 di SD Negeri 38 Ampenan. Fakta telah menunjukkan perolehan rata-rata skor aktivitas dan hasil belajar siswa pada siklus I $(3,43)$, sedangkan pada siklus II $(4,65)$, hasil belajar dari 69,48 menjadi 81,68 sudah melampaui Indikator keberhasilan yang ditetapkan. Penelitian dinyatakan "berhasil" dan dihentikan pada siklus II.

Data komulatif dari hasil penelitian tindakan kelas (PTK) dari siklus I ke Siklus II adalah sebagai berikut: 


\begin{tabular}{|c|l|c|c|c|c|c|c|}
\hline \multirow{2}{*}{ No } & \multirow{2}{*}{ Jenis Kegiatan } & \multirow{2}{*}{$\begin{array}{c}\text { Indikator } \\
\text { Keberbasilan }\end{array}$} & \multicolumn{2}{|c|}{ Siklus I } & \multicolumn{2}{c|}{ Siklus II } & \multirow{2}{*}{ Ket } \\
\cline { 4 - 7 } & & I & II & I & II & \\
\hline 1. & Hasil Observaasi Guru & $\geq 4,00$ & 3,21 & 3,43 & 4,21 & 4,57 & Tuntas \\
\hline 2 & Observasi Siswa & $\geq 4,00$ & 3,35 & 3,70 & 4,20 & 4,65 & Tuntas \\
\hline 3. & Hasil Tugas Individual & $\geq 75,00$ & 70,80 & - & 80,95 & - & Tuntas \\
\hline & Hasil Tes tertulis & $\geq 75,00$ & - & 68,15 & - & 82,40 & Tuntas \\
\hline
\end{tabular}

Saran

Disarankan kepada guru sejawat untuk melaksanakan Penelitian Tindakan Kelas (PTK) dalam upaya untuk meningkatkan aktivitas dan hasil dan hasil belajar siswa sesuai dengan mata pelajaran masing-masing.

Disarankan kepada para semua siswa kelas III SD Negeri 38 Ampenan untuk membiasakan belajar dengan pendekatan yang kontekstual utamanya strategi yang mampu membangkitkan aktivitas dan hasil dan hasil belajar siswa yang dampaknya prestasi belajar dapat ditingkatkan seperti yang diharapkan.

\section{DAFTAR PUSTAKA}

Anonim, 2018, dalam https://ekokhoerul.wordpress.com/2012/ 06/27/konsep-aktivitas-belajar-siswa/, diambil tanggal 29 Juli 2018, pukul 17.46 Wita.

Anonim, 2018, dalam http://ainamulyana.blogspot.co.id/2012/ 01/pengertian-hasil-belajar-danfaktor.html, diambil tanggal 29 Juli 2018, Pukul 19.54 Wita

Anonim, 2018, dalam http://caramengajarefektif.blogspot.com /2016/03/metode-small-group-

discussion.html, diambil tanggal 29 Juli 2018, Pukul 23.42 Wita

Al Hakim, S dan Riyanto, M, 2002, strategi Pembelajaran Berdasarkan Deep Dialogue/Critical Thinking (DD/CT), Malang: PPPG IPS dan PMP

Arikunto, s. 2009, Penelitian Tindakan Kelas, Jakarta : Bumi Aksara.

Harun Rasyid dan Mansur, 2008, Penilaian Hasil Belajar, Bandung : CV Wacana Prima.

Lie, A, 2002, Cooperative Learning, Jakarta: Gramedia Widiasarma Indonesia.

Lukmanul A, 2008, Perencanaan Pembelajaran, Bandung : CV Wacana Prima.
Mukhtar, 2003, Prosedur Penilaian, Jakarta : Rineka Cipta.

Nurhadi, 2003, Yasin ,B dan Sendule.A, 2003, Kontekstual dan Penerapannya dalam KBK, Malang : Unitipetas Negeri Malang.

Robert E Slavin, 2010, Cooperative Learning Teori, riset dan Praktik, Bandung : Nusa Media.

Sardiman, 2007, Indikator Dan Aktivitas dan hasil Belajar Mengajar, Jakarta : Raja Grafindo Perkasa.

Supriono, 2009, Cooperative Learning Teori dan Aplikasi PAIKEM, Yogyakarta : Pustaka Pelajar. 